\title{
Constraints Faced by Paddy Farmers and Suggestions for Effective Utilization of Android App on Paddy Expert System
}

\author{
C. K. Nivedha ${ }^{1 *}$ and C. Karthikeyan ${ }^{2}$ \\ Department of Social Sciences, Agricultural College and Research Institute, \\ Thoothukudi, Tamil Nadu, India \\ *Corresponding author
}

\begin{abstract}
A B S T R A C T
Keywords

Apps on expert system, Market price, Awareness, Utilization

\section{Article Info}

Accepted:

15 August 2020

Available Online:

10 September 2020

Agriculture is the most important sector in the Indian economy. It also plays a significant role in sustaining the security of livelihood for the country's millions of farmers. An expert system (ES) is a computer programme that is designed to emulate the logic and reasoning processes that an expert would use to solve a problem in his/her field of expertise, using artificial intelligence technology. The present study explored the constraints faced by paddy farmers and suggestions for effective utilization of paddy expert system app. The present study was carried out during December 2019 among paddy growers in the Vasudevanallur Block of Tirunelveli district. It was revealed that lack of awareness about the paddy expert system app, lack of updation of new farm problems with solution and lack of update about market price were the major constraints in paddy expert system app. All these constraints can be overcome by implementing suggestions provided by farmers like necessity for mass media advertisements/publicity regarding the app on paddy expert system could enhance the awareness among farmers, recent information about market price, new farm problems should be updated regularly on paddy expert system app. The study results will allow the expert system designers to adjust the content and procedures to match end users' expectation. The extension workers will have to demonstrate and train users in handling and using different mobile apps on expert system available in the public domain.
\end{abstract}

\section{Introduction}

Agriculture is the most important sector in the Indian economy. It also plays a significant role in sustaining the security of livelihood for the country's millions of farmers. Apart from this, India is also a forerunner in IT sector. ICT can be used to provide farmers with reliable information and services, thereby promoting a more remunerative agriculture development (Raguprasad et al., 2012). ICT is a paraphrase which covers all advanced Information Manipulation and Communication Technologies. Infrastructure of ICT has the potential for a drastic improvement in quality of life and has thus become a important dimension of rural development (Leatherman, 2000). An expert system (ES) is a computer programme that is designed to emulate the logic and reasoning 
processes that an expert would use to solve a problem in his/her field of expertise, using artificial intelligence technology (Waterman, 1986). Expert system can be used as a decision support tool for farmers in developing countries such as India to conduct agricultural extension service (Sivakami and Karthikeyan, 2008). Expert system consists of three components such as decision support system, crop doctor and information system. In this information age, the available information from various sources is growing at phenomenal rate and Tamil Nadu Agricultural University (TNAU) has recently introduced a bilingual version of six mobile apps on expert system in coconut, paddy, banana, rice, sugarcane and livestock which were made available in Google play store and in m-apps.gov.in for the benefit of farmers, extension officials, researchers and students (Karthikeyan, 2018). The common problems with ICT adoption in rural segments are lack of literacy, availability of relevant content and localization in their own languages, easy and affordable access, and other issues such as awareness and willingness among rural people to adopt new technologies (Abhishek et al., 2019). With proper approachability, ICT will bring about change in the agrarian society. Here, an attempt has been made to analyze the constraints and their possible solutions perceived towards the utilization of android app on expert system in paddy.

\section{Materials and Methods}

The present study was carried out during December 2019 to January 2020 among paddy farmers in the Vasudevanallur block of the Tirunelveli district. Tirunelveli district had 19 blocks. Of these, Vasudevanallur block had maximum area under paddy crop and hence it was selected for the study. Thus 60 samples were selected as respondents for this study. Thus required number of respondents was selected by using random proportionate random sampling technique. An Ex-post facto research design was used for this study. From the respondents, data were collected with the help of well structured interview schedule. The collected data was statistically analyzed using SPSS Software.

\section{Results and Discussion}

\section{Constraints in using the android app on expert system in paddy}

Identifying the constraints would project the field dimension problems faced by the respondents. The details of the constraints encountered by the paddy farmers in handling the app on Paddy expert system was collected, analyzed and ranked based on percentage and presented in the Table 1.

It could be seen from the table 1 that 60 per cent of the paddy farmers stated that they were unaware about the existence of the app. They felt that more awareness about the paddy expert system app among farmers needs to be created for realization of the benefit by large number of farmers. These findings are similar with the findings of (Sunil rajoria et al., 2017). More than half (53.3\%) of the paddy farmers stated that lack of updating of new farm problems with solutions in the expert system as one of the constraints. Half $(50 \%)$ of the paddy farmers stated that lack of dynamic updates about market prices. Information about the domestic market, export standards was given in the app but the market price of the farm produce was not updated. The findings of the present study are in line with the results obtained by (Santhiya and Elakkiya, 2017) in their study on the constraints encountered by famers in ICT utilization which stated that 60 per cent of the farmers faced the problem of lack of clarity about price fixation in market. About 45 per cent of the paddy farmers stated that limited questions covering the cultivation problems 
was given in the expert system, therefore they can't fulfill their clarification about other doubts that arose in cultivation practices.
About 41.6 per cent of the paddy farmers stated that lack of information about availability of inputs as another constraint.

Table.1 Constraints in using the android app on expert system in paddy ( $\mathrm{n}=60$ )

\begin{tabular}{|c|c|c|c|c|}
\hline $\begin{array}{l}\text { S. } \\
\text { No. }\end{array}$ & Constraints & Number* & Per cent & Rank \\
\hline 1 & $\begin{array}{l}\text { Awareness about the existence of the app } \\
\text { is less among farmers }\end{array}$ & 36 & 60 & I \\
\hline 2 & $\begin{array}{l}\text { Lack of updation of new farm problems } \\
\text { with solution in the app }\end{array}$ & 32 & 53.3 & II \\
\hline 3. & Lack of update about market price & 30 & 50 & III \\
\hline 4 & $\begin{array}{l}\text { Limited questions about cultivation } \\
\text { problems were given in FAQs }\end{array}$ & 27 & 45 & IV \\
\hline 5. & $\begin{array}{l}\text { Lack of information about availability of } \\
\text { inputs }\end{array}$ & 25 & 41.6 & $\mathrm{~V}$ \\
\hline 6. & $\begin{array}{l}\text { Lack of information about newly } \\
\text { released varieties under institute content }\end{array}$ & 20 & 33.3 & VI \\
\hline 7. & $\begin{array}{l}\text { Non - availability of video clips for some } \\
\text { information under cultivation practices } \\
\text { section }\end{array}$ & 18 & 30 & VII \\
\hline
\end{tabular}

* Multiple responses

Table.2 Suggestions for effective utilization among paddy farmers $(n=60)$

\begin{tabular}{|c|l|c|c|c|}
\hline S. No. & \multicolumn{1}{|c|}{ Suggestions } & Number* & Per cent & Rank \\
\hline $\mathbf{1}$ & $\begin{array}{l}\text { More mass media awareness on paddy } \\
\text { expert system app may be given for } \\
\text { wider publicity }\end{array}$ & 34 & 56.6 & I \\
\hline $\mathbf{2}$ & $\begin{array}{l}\text { Provision may be made for automatic } \\
\text { updation of new farm problems with } \\
\text { solution in the app }\end{array}$ & 31 & 51.6 & II \\
\hline $\mathbf{3 .}$ & $\begin{array}{l}\text { Market price of Paddy should be } \\
\text { updated in the app dynamically. }\end{array}$ & 29 & 48.3 & III \\
\hline $\mathbf{4 .}$ & $\begin{array}{l}\text { Wider scope of questions about } \\
\text { cultivation problems should be included } \\
\text { in the FAQs content }\end{array}$ & 27 & 45 & IV \\
\hline $\mathbf{5 .}$ & $\begin{array}{l}\text { Information about availability of inputs } \\
\text { may be given }\end{array}$ & 26 & 43.3 & V \\
\hline $\mathbf{6 .}$ & $\begin{array}{l}\text { Information about newly released } \\
\text { varieties should be updated }\end{array}$ & 21 & 35 & VI \\
\hline $\mathbf{7 .}$ & $\begin{array}{l}\text { Interactive video based instruction } \\
\text { system may be developed for all stages } \\
\text { of the crop }\end{array}$ & 19 & 31.6 & VII \\
*-Multiple responses & & & \\
\hline
\end{tabular}


The description of the inputs was given, but the information about the availability of inputs was not given in the paddy expert system app. About one-third (33.3\%) of the paddy farmers stated that lack of information about newly released varieties under institute content in the paddy expert system app as a constraint. The information about varieties released by the institutes was given but the information about newly released varieties were not updated under institute content. About 30 per cent of the paddy farmers stated non-availability of video clips for some information under institution section as a constraint. The video clips about the latest technologies in Paddy were not given in the paddy expert system. The findings of the present study are in line with the results obtained by Navinkumar et al., (2018) in their study on constraints faced by the farmers in using mobile agro-advisory services, wherein it was stated that lack of video information on mobile agro-advisory services as one of the constraint.

\section{Suggestions for effective utilization among paddy farmer}

Further attempts were made to gather suitable suggestions for effective utilization of the app on paddy expert system by the paddy farmers. The details of the suggestions reported by the respondents were collected, analyzed based on percentage and presented in the Table 2.

It could be seen from the table 2 that more than half $(56.6 \%)$ of the paddy farmers suggested that farmers were not aware of the existence of the app and hence more awareness programmes on paddy expert system app need to be organized for wider publicity. Mass media advertisements/ publicity regarding the app on paddy expert system would enhance the awareness among farmers. About 51.6 per cent of the paddy farmers suggested that provision may be made for automatic updation of new farm problems with appropriate solutions in all the installed system. The solution for existing farm problems were given, but the solution for new farm problems were not updated in the paddy expert system. The findings of the present study are in line with the results obtained by Abishek et al., (2020) on their study on the constraints faced by farmers and suggestions for effective utilization of ICT services in agriculture in central UP which suggested that the messages should be timely to the farmers therefore; the farmers will plan their operations. Nearly half $(48.3 \%)$ of the paddy farmers suggested that market price should be updated dynamically. The information about the domestic markets, export standard was given, but the market price was not updated, so they felt that market price should be updated. About 43.3 per cent of the paddy farmers suggested that availability of the farm implements should be given in the expert system. The description of farm implements were given, but the availability of farm implements were not given, so they suggested the information regarding farm implements availability should be given in the paddy expert system. About 35 per cent of the paddy farmers suggested that information about newly released varieties should be updated. The information about the varieties released by the various institutes was given in the app, but it was not updated. So they suggested updating the information about newly released varieties in the app. About 31.6 per cent of the paddy farmers suggested that they need interactive video based guiding system to be developed for all stages of the crop in the app. The findings of the present study are in line with the results obtained by Navinkumar et al., (2018) in their study on constraints faced by the farmers in using mobile agro-advisory services which stated that the farmers needed a short video message because the video brings consistency and clarity, involve more 
sensory organs which could be one of the reasons farmers desired.

In conclusion each technology is like two sides of the coin, everything has both advantages, and constraints. Agricultural growth in the current scenario depends on bridging the knowledge gap among end users. In this regard, ICT enables better improvement in agriculture. It is clear from the study that majority of the paddy farmers felt that lack of awareness about the app, lack of updation of new farm problems with solution and lack of update about market price as the constraints in the utilisation of the app on paddy expert system. These constraints could be overcome through creation of awareness programmes on paddy expert system app to be organized for wider publicity. Mass media advertisements/ publicity regarding the app on paddy expert system would enhance the awareness among farmers, recent information about market price and new farm problems should be updated regularly on paddy expert system app. The study results will allow the expert system designers to adjust the content and procedures to match end users' expectation. The extension workers will have to demonstrate and train users in handling and using different useful mobile apps on expert system created by TNAU or other authentic sources.

\section{References}

Abhishek Mishra, OP Yadav, Vishakha Yadav and Swatantra Pratap Singh. 2020. Constraints faced by farmers and suggestions for effective utilization of
ICT services in agriculture in central UP. The Pharma Innovation Journal 2020; 9(2): 121-124

Leatherman J. Internet-based commerce: Implications for rural communities Kansas City: Kansas State University, 2000.

Navinkumar, Dhananjaya, Hanumanthappa and Ranjeeth. 2020. Constraints Faced By the Farmers in Using Mobile AgroAdvisory

Services.

Int.J.Curr.Microbiol.App.Sci

(2018)

Special Issue-6: 2885-2890

Raghuprasad K P, Devaraja S C, and Gopala Y M, 2012. Attitude of Farmers towards Utilization of Information Communication Technology (ICT) Tools in Farm Communication. Research Journal of Agricultural Sciences, 3(5), 1035-1037

Sivakami, S. and Karthikeyan, C. 2008. Evaluating the effectiveness of expert system for performing agricultural extension services in India. Expert System with Application, 6, 9634-9636.

Sunil Rajoria, Sanjay Kumar Rewani, Virendra Singh, Manisha Singodia, Gara Ram Saini and Rohitash Kumar. 2017. Constraints Perceived by Livestock Farmers in Use of ICTs in Jaipur District of Rajasthan, India. Int.J.Curr.Microbiol.App.Sci. $\quad$ 6(12): 1834-1839.

Shanthya M.S and Elakkiya S 2017. Constraints Encountered by Famers in ICT Utilization- an Analysis. International Journal of Agriculture Innovations and Research Volume 6, Issue 2: 2319-1473

\section{How to cite this article:}

Nivedha, C. K. and Karthikeyan, C. 2020. Constraints Faced by Paddy Farmers and Suggestions for Effective Utilization of Android App on Paddy Expert System. Int.J.Curr.Microbiol.App.Sci. 9(09): 1636-1640. doi: https://doi.org/10.20546/ijcmas.2020.909.203 